\title{
The Development of Small and Medium Businesses (MSMEs) Based on Tecnology to Deal with The Industrial Revolution 4.0
}

\section{Qotrunnada Ratri Hamidah, Agung Tri Pambudi Sejati, Ana Zulfatu Mujahidah}

Universitas Sebelas Maret

nadaratri@student.uns.ac.id

\section{Article History}

accepted 24/09/2019

\begin{abstract}
This article aims to find out the procedures for the development of technology-based Micro, Small and Medium Enterprises (MSMEs) to face the era of the industrial revolution 4.0. The research method used is the study of literature. Data collection is carried out by conducting a study of the review of books, literature, notes, and reports that have to do with the problem being solved. The sources of literature in this study were obtained from books, journals, and research results (papers, theses, and theses) so in this article include general processes which include: systematically identifying theories, finding literature, and analyzing documents that contains information related to the research topic. The results of this study are expected to find ways to develop production results in technology-based Micro Small and Medium Enterprises (MSMEs) to be able to compete in the international class to support Indonesia towards the industrial revolution era 4.0.
\end{abstract}

Keywords: Micro, Small and Medium Enterprises, Technology, Industrial Revolution 4.0

\begin{abstract}
Abstrak
Artikel ini bertujuan untuk mengetahui tata cara pengembangan Usaha Mikro Kecil dan Menengah (UMKM) yang berbasis teknologi untuk menghadapi era revolusi industri 4.0. Metode penelitian yang digunakan yakni dengan studi kepustakaan. Pengumpulan data dilakukan dengan mengadakan studi penelaahan buku-buku, literatur-literatur, catatan-catatan, dan laporan-laporan yang ada hubungannya dengan masalah yang dipecahkan. Sumber-sumber kepustakaan dalam penelitian ini diperoleh dari buku-buku, jurnal, dan hasil penelitian (makalah, skripsi, dan tesis) sehingga dalam artikel ini meliputi proses-proses umum yang meliputi : mengidentifikasi teori secara sistematis, penemuan pustaka, dan analisa dokumen yang memuat informasi yang berkaitan dengan topik penelitian. Hasil penelitian ini diharapkan dapat menemukan cara mengembangkan hasil produksi pada Usaha Mikro Kecil dan Menengah (UMKM) berbasis teknologi agar mampu bersaing di kelas internasional untuk mendukung Indonesia menuju era revolusi industry 4.0.
\end{abstract}

Kata kunci: Usaha Mikro Kecil dan Menengah, Teknologi, Revolusi Industri 4.0

Social, Humanities, and Education Studies (SHEs): Conference Series https://jurnal.uns.ac.id/shes

p-ISSN 2620-9284

e-ISSN 2620-9292 


\section{PENDAHULUAN}

Saat ini dunia telah mengalami era revolusi industri 4.0. Seluruh negara berlomba untuk bersaing dalam kemajuan dan menciptakan inovasi agar mampu bersaing di dunia internasional. Negara maju menciptakan mesin baru yang mendukung era ini. Termasuk Indonesia yang berusaha untuk menyesuaikan keaadaan menjadi negara yang menggunakan teknologi revolusi industri 4.0. Era dimana analog menjadi digital. Pesatnya kemajuan internet dan teknologi. Mesin yang memiliki kemampuan canggih bahkan bisa berpikir seperti manusia. Era revolusi industri 4.0 beberapa dekade ini sedang "meledak" hal tersebut ditandai dengan munculnya pembaharuan disegala bidang kehidupan tak terkecuali Usaha Mikro Kecil dan Menengah (UMKM) yang merupakan industri yang hampir digeluti oleh sebagian besar masyarakat di Indonesia.

Keberadaan Usaha Mikro Kecil dan Menengah (UMKM) tidak dapat dihapuskan ataupun dihindarkan dari masyarakat bangsa saat ini. Karena keberadaannya sangat bermanfaat dalam hal pendistribusian pendapatan masyarakat. Selain itu juga mampu menciptakan kreatifitas yang sejalan dengan usaha untuk mempertahankan dan mengembangkan unsur-unsur tradisi dan kebudayaan masyarakat setempat. Pada sisi lain, Usaha Mikro Kecil dan Menengah (UMKM) mampu menyerap tenaga kerja dalam skala yang besar mengingat jumlah penduduk Indonesia yang besar sehingga hal ini dapat mengurangi tingkat pengangguran. Dari sinilah terlihat bahwa keberadaan Usaha Mikro Kecil dan Menengah (UMKM) yang bersifat padat karya, menggunakan teknologi yang sederhana dan mudah dipahami mampu menjadi sebuah wadah bagi masyarakat untuk bekerja dan mendapatkan pengahasilan yang cukup untuk kebutuhan mereka.

Program pengembangan Usaha Mikro, Kecil, dan Menengah (UMKM) sebagai salah satu instrument untuk menaikkan daya beli masyarakat, pada akhirnya akan menjadi katup pengaman dari situasi krisis moneter. Pengembangan UMKM menjadi sangat strategis dalam menggerakkan perekonomian nasional, mengingat kegiatan usahanya mencakup hampir semua lapangan usaha sehingga kontribusi UMKM menjadi sangat besar bagi peningkatan pendapatan bagi masyarakat berpendapatan rendah.

Perkembangan Usaha Mikro Kecil dan Menengah (UMKM) di Indonesia memang cukup pesat selama beberapa tahun terakhir. Namun, masih ada saja masalah Usaha Mikro Kecil dan Menengah (UMKM) Indonesia yang belum diatasi secara maksimal. Terutama Usaha Mikro Kecil dan Menengah (UMKM) yang berada di pedesaan yang jauh dari internet maupun teknologi. Masih menggunakan alat tradisonal dan pemasaran yang masih menggunakan sistem pemasaran tradisional yang dinilai kurang menjangkau pemasaran yang luas. Hal ini membuat pelaku Usaha Mikro Kecil dan Menengah (UMKM) tidak mengalami kemajuan. Padahal saat ini telah mengalami era revolusi Industri 4.0, yang seharusnya setiap Usaha Mikro Kecil dan Menengah (UMKM) dapat megoptimalkan baik dari proses produksi ataupun cara pemasarannya agar omset yang didapat meningkat.

Menteri Perhubungan, Budi Karya menjelaskan UMKM di Indonesia menyerap 96\% tenaga kerja dan berkontribusi 60\% PDB ( Produk Domestik Bruto). Namun untuk menghadapi era Revolusi Industri 4.0 yang berbasis teknologi, maka perlu ada pengembangan karena baru 5\% yang go digital. Disampaikan dalam Seminar dan Dialog Nasional bertajuk "Kesiapan UMKM dan Ekonomi Kerakyatan di Era Revolusi 4.0" sebagai pembicara sekaligus sebagai Ketua Koordinator Presidium Perhimpunan Perguruan Tinggi Negeri (Himpuni). (m.detik.com, Selasa, 12 Maret 2019).

Berdasarkan latar belakang ini, dalam tulisan ini akan dibahas tentang bagaimanakah cara pengembangan Usaha Mikro Kecil dan Menengah (UMKM) berbasis teknologi untuk menghadapi era revolusi industri 4.0 agar produk dapat bersaing baik di kelas nasional maupun internasional. 


\section{METODE}

Metode yang digunakan dalam kajian ini menggunakan metode atau pendekatan kepustakaan (library research), studi pustaka atau kepustakaan dapat diartikan sebagai serangkaian kegiatan yang berkenaan dengan metode pengumpulan data pustaka, membaca dan mencatat serta mengolah bahan penelitian (Zed, 2003:3). Dalam penelitian studi pustaka setidaknya ada empat ciri utama yang penulis perlu perhatikan diantaranya : pertama, bahwa penulis atau peneliti berhadapan langsung dengan teks (naskah) atau data angka, bukan dengan pengetahuan langsung dari lapangan. Kedua, data pustaka bersifat "siap pakai" artinya peniliti tidak terjun langsung kelapangan karena peneliti berhadapan langsung dengan sumber data yang ada di perpustakaan. Ketiga, bahwa data pustaka umumnya adalah sumber sekunder, dalam arti bahwa peneliti memperoleh bahan atau data dari tangan kedua dan bukan data orisinil dari data pertama di lapangan. Keempat, bahwa kondisi data pustaka tidak dibatasi oleh runga dan waktu (Zed, 2003:4-5).

Berdasarkan dengan hal tersebut diatas, maka pengumpulan data dalam penelitian dilakukan dengan menelaah dan/atau mengekplorasi beberapa jurnal, buku, dan dokumen-dokumen (baik yang berbentuk cetak maupun elektronik) serta sumbersumber data dan atau informasi lainnya yang dianggap relevan dengan penelitian atau kajian.

\section{Pengertian Usaha Mikro Kecil dan Menengah}

\section{HASIL DAN PEMBAHASAN}

Menurut Rudjito (2003) Mengemukakan bahwa pengertian Usaha Mikro Kecil dan Menengah (UMKM) adalah usaha yang punya peranan penting dalam perekonomian Negara Indonesia, baik dari sisi lapangan kerja yang tercipta maupun dari sisi jumlah usahanya.

Pada Bab I pasal 1 UU No 20 Tahun 2008 tentang Usaha Mikro, Kecil, dan Menengah (UMKM), maka yang dimaksud dengan Usaha Mikro, Kecil, dan Menengah adalah: 1) Usaha Mikro adalah usaha produktif milik orang perorangan dan/atau badan usaha perorangan yang memenuhi kriteria Usaha Mikro sebagaimana diatur dalam Undang-Undang ini. 2) Usaha Kecil adalah usaha ekonomi produktif yang berdiri sendiri, yang dilakukan oleh orang perorangan atau badan usaha yang bukan merupakan anak perusahaan atau bukan cabang perusahaan yang dimiliki, dikuasai, atau menjadi bagian baik langsung maupun tidak langsung dari. Usaha Menengah atau Usaha Besar yang memenuhi kriteria Usaha Kecil sebagaimana dimaksud dalam undang-undang ini. 3) Usaha Menengah adalah usaha ekonomi produktif yang berdiri sendiri, yang dilakukan oleh orang perorangan atau badan usaha yang bukan merupakan anak perusahaan atau cabang perusahaan yang dimiliki, dikuasai, atau menjadi bagian baik langsung maupun tidak langsung dengan Usaha Kecil atau Usaha Besar dengan jumlah kekayaan bersih atau hasil penjualan tahunan sebagaimana diatur dalam Undang-Undang ini.

Berdasarkan definisi di atas maka dapat disimpulkan bahwa Usaha Mikro Kecil dan Menengah (UMKM) adalah suatu bentuk usaha ekonomi produktif yang dilakukan oleh orang perseorangan atau badan usaha perorangan yang memenuhi kriteria Usaha Mikro, Kecil, dan Menengah (Jurnal Administrasi Publik (JAP), Vol. 1, No. 6, Hal. 1286-1295)

\section{Pengertian Revolusi Industri 4.0}

Menurut Zimmerman (2018) bahwa era revolusi industri 4.0 dan selanjutnya akan melibatkan pekerjaan pada kemampuan sains, teknologi, tehnik dan matematika, internet of things, pembelajaran sepanjang hayat sebanyak $75 \%$.

Menurut Presiden Indonesia ke 7, Ir. Joko Widodo, bahwa revolusi industri 4.0 telah mendorong inovasi-inovasi teknologi yang memberikan dampak disrupsi atau perubahan yang fundamental terhadap kehidupan masyarakat. 
Dalam sejarah revolusi industri 4.0 berasal dari proyek dalam strategi teknologi canggih yang dimunculkan oleh pemerintah Jerman yang lebih menekankan pada komputerisasi pabrik. Hingga tahun 2011, istilah industri 4.0 kemudian diangkat kembali pada acara Honnover Fair. Kelanjutannya dari hal ini pada oktober 2012 dlam Working Group On Industry 4.0 menjelaskan bahwa rekomendasi pelaksanaan industry 4.0 kepada pemerintah federal Jerman. Dalam kelompok kerja Industri 4.0 yang kemudian dalam anggota tersebut sebagai bapak pendiri dan perintis Industri 4.0 memaparkan pada tanggal 8 April 2013 dalam acara Hannover Fair.

Dari sejarah dan beberapa pendapat tersebut dapat disimpulkan bahwa era revolusi industri 4.0 adalah fase teknologi yang merubah dapat merubah pola kehidupan manusia, yang akan melibatkan pekerjaan pada kemampuan sains, teknologi, tehnik dan matematika, internet of things yang akan memberikan perubahan yang fundamental terhadap kehidupan masyarakat.

\section{Pengertian Teknologi}

Djoyohadikusumo (1994) mendefinisikan mengenai pengertian teknologi sebagai suatu bidang yang berkaitan erat dengan ilmu sains dan ilmu kerekayasaan atau ilmu engineering. Dapat disimpulkan bahwa pada dasarnya teknologi bisa disebut memiliki dua dimensi, yaitu dimensi engineering dan juga dimensi science. Kedua dimensi itu akan saling terkati selam perkembangan dan juga penciptaan dari sebuah teknologi, dan tidak bisa terpisahkan.

Menurut Kamus Besar Bahasa Indonesia (KBBI) Teknologi adalah metode ilmiah untuk mencapai tujuan praktis; ilmu pengetahuan terapan; keseluruhan sarana untuk menyediakan barang-barang yang diperlukan bagi kelangsungan dan kenyamanan hidup manusia.

Kesimpulannya Teknologi adalah keseluruhan proses dan sarana untuk menyediakan barang-barang yang diperlukan bagi kelangsungan dan kenyamanan hidup manusia, yang berkaitan erat dengan ilmu sains dan ilmu kerekayasaan atau ilmu engineering.

\section{Cara mengembangkan Usaha Mikro Kecil dan Menemgah (UMKM) berbasis teknologi untuk menghadapi era revolusi industri 4.0}

Revolusi industri 4.0 merupakan fase revolusi teknologi yang mengubah cara beraktivitas manusia dalam skala, ruang lingkup, kompleksitas, dan transformasi dari pengalaman hidup yang sebelumnya. Prinsip dasar revolusi industri 4.0 adalah menggabungkan mesin, alur kerja, dan sistem dengan menerapkan jaringan cerdas di sepanjang rantai dan proses produksi. Hal ini bertujuan untuk mengendalikan satu sama lain secara mandiri. Perkembangan teknologi yang pesat akan mendorong perubahan perilaku masyarakat, dan peningkatan kebutuhan akan mendorong berubahnya dan terciptanya peluang bisnis dan pekerjaan baru.

Perubahan dan peluang bisnis yang baru didorong dengan perkembangan penggunaan internet. Dimana peluang ini juga disadari oleh para pelaku bisnis untuk memanfaatkan internet dalam proses berbisnis. Penggunaan internet dalam proses berbisnis akan terus mengalami perkembangan. Mulai dari pertukaran informasi secara elektronik ke aplikasi strategi bisnis, pemasaran, penjualan, hingga pelayanan pelanggan. Internet juga akan mendukung komunikasi dan kerja sama global antara karyawan, konsumen, penjual, dan rekan bisnis yang lainnya. Selain itu, internet juga memungkinkan orang dari suatu organisasi atau lokasi yang berbeda dapat bekerja sama sebagai satu tim virtual untuk mengembangkan, memproduksi, memasarkan, dan memelihara produk atau pelayanan.

Cara mengembangkan Usaha Mikro Kecil dan Menengah berbasis Teknologi menurut M. Alfian Mizar antara lain dengan cara : 1)Penerapan IPTEK melalui rekayasa, manufaktur dan mesin mesin Planner, dan perangkat peralatan finishing produk. 2)Implementasi Iptek melalui pengembangan produk berpotensi pasar nasional dan ekspor, meliputi: penganeka ragaman produk, kualitas desain produk sesuai 
dengan perkembangan Ipteks dan filosofi masyarakat tujuan pemasaran, serta teknologi finishing produk. 3) Penataan lay out mesin/ peralatan produksi yang dilakukan bersama-sama dengan pihak UKM untuk memudahkan alur penyiapan bahan dan alur proses produksi sampai dengan finishing produk. 4) Penataan manajemen: (a) penerapan manajemen produksi, (b) manajemen pengembangan sumber daya manusia (penguasaan desain produksi dan sekaligus bertindak sebagai quality controle, (c) manajemen keuangan dan penerapan software akutansi dan administrasi usaha.5) Perluasan pangsa pasar dengan pembuatan katalog dan website produk, pengembangan pasar dalam negeri, dan menjalin kerjasama/ kemitraan yang lebih luas, terutama dengan mitra eksportir.

Dampak dari pengunaan Teknologi dalam meningkatkan Usaha Mikro Kecil dan Menengah antara lain :1) Dapat mengatasi permasalahan peningkatan kuantitas dan kualitas produk, melalui implementasi mesin dan peralatan produksi. 2) Pengembangan produk berpotensi pasar nasional dan ekspor, melalui peningkatan technical skill dan manajemen skill didampingi oleh ahli pada bidangnya guna meningkatkan kualitas desain, produk, peningkatan kapasitas produk, dan aplikasi software manajemen usaha, serta desain web on-line untuk pemasaran produk UMKM. 3) Memudahkan alur proses produksi dan meningkatkan keselamatan dan kenyamanan kerja.4) Dapat melakukan perluasan pangsa pasar nasional dan ekspor.5) Terjadi peningkatan jumlah karyawan, dan peningkatan omset produk.

\section{SIMPULAN}

Dengan menerapkan teknologi untuk mengembangkan UMKM untuk menghadapi era revolusi industri 4.0 diharapkan dapat mengatasi permasalahan peningkatan kuantitas dan kualitas produk, dapat diimplementasikan Ipteks melalui rekayasa, manufaktur dan pengadaan mesin Planner, dan perangkat peralatan finishing produk. Implementasi Iptek melalui pengembangan produk berpotensi pasar nasional dan ekspor, dilakukan dengan cara peningkatan technical skill dan manajemen skill dalam bentuk pelatihan dan pendampingan kepada para pengusaha guna peningkatan kualitas desain, kualitas produk, peningkatan kapasitas produksi, dan aplikasi software manajemen usaha, serta desain web on-line untuk pemasaran produk UMKM. Perluasan pangsa pasar nasional dan ekspor, melalui mitra pemasaran. Terjadi peningkatan jumlah karyawan, dan peningkatan omset.

\section{DAFTAR PUSTAKA}

Anggraeni, Feni Dwi,dkk. (2013). Pengembangan Usaha Mikro Kecil dan Menegah (UMKM) Melalui Fasilitas Pihak Eksternal dan Potensi Internal (Studi Kasus pada Kelompok Usaha "Emping Jagung" di Kelurahan Pandanwangi Kecamatan Blimbing Kota Malang. Malang:Penulis.

Azqiara. (2019, Januari 31). Pengertian UMKM Secara Umum dan Menurut Para Ahli Lengkap. ID Pengertian. Diunduh tanggal 28 September 2019 dari https://www.idpengertian.com/pengertian-umkm-secara-umum-dan-menurutpara-ahli-lengkap/\#Rudjito

Mizar, M. Alfian. dkk. (2014). Pengembangan Industri Kreatif Berbasis Bhan Baku Kayu di Malang-Jatim. Malang: Penulis.

Purbaya, Angling Andhitya. (2019, Maret 12). Masalah UMKM di RI: Minim Melek Teknologi hingga Sulit Akses Modal. Detik Finance. Diakses tanggal 28

September 2019 dari https://m.detik.com

https://www.artikelsiana.com/2019/01/revolusi-industri-40-pengertian-ciri-dampak-

tantangan-industri-40.html\# diunduh tanggal 29 September 2019.

https://kbbi.web.id/teknologi diunduh pada tanggal 28 September 2019.

https://www.jurnal.id/id/blog/peluang-bisnis-baru-di-era-revolusi-industri-4-0/ 
4th National Seminar on Educational Innovation (SNIP 2019)

SHEs: Conference Series 2 (1) (2019) $345-349$ 